\title{
STRUCTURAL SPECIFICITY FOR BIOLOGICAL ACTIVITY OF TRICHOSTATIN A, A SPECIFIC INHIBITOR OF MAMMALIAN CELL CYCLE WITH POTENT DIFFERENTIATION-INDUCING ACTIVITY IN FRIEND LEUKEMIA CELLS
}

\author{
Minoru Yoshida, Yutaka Hoshikawa, Koshi Koseki, \\ KENJI MORI and TERUHIKo BEPPU
}

\author{
Department of Agricultural Chemistry, Faculty of Agriculture, The University of Tokyo, \\ Yayoi 1-1-1, Bunkyo-ku, Tokyo 113, Japan \\ (Received for publication February 14, 1990)
}

\begin{abstract}
Biological activities of four chemically synthesized trichostatin-related compounds, $(R)$ trichostatin A, $(S)$-trichostatin A, $(R)$-trichostatic acid, and $(S)$-trichostatic acid, were investigated. Assays of differentiation-inducing activity in Friend leukemia cells and $\mathrm{G}_{2}$-arresting activity in the cell cycle of normal rat fibroblast cells were used as monitoring systems for comparing the bioactivities of these compounds. The results clearly showed that both of the enantiomers of trichostatic acid had no activity in both the assay systems. In the case of $(S)$-trichostatin $\mathrm{A}$, the antipode of naturally occurring trichostatin A, 50\% effective concentrations were determined to be $50 \sim 70$-fold higher than those of $(R)$-trichostatin A. The relationship between this ratio and the value of enantiomeric excess strongly suggests that $(S)$-trichostatin $A$ is also biologically inactive. These results indicate that the absolute configuration and the presence of the hydroxamate group of trichostatin $A$ are essential for its biological activity.
\end{abstract}

Trichostatins A and C (Fig. 1), which had been originally discovered as fungistatic antibiotics by TsuJI $e$ t al., TSUI and KOBAYASHI ${ }^{1,2)}$, were also found by our group to be very potent inducers of erythroid differentiation in mouse Friend leukemia cells ${ }^{3,4}$. More interestingly, we found that a low concentration of trichostatin A reversibly blocked the cell cycle of normal fibroblast cells at both the $G_{1}$ and $G_{2}$ phases and induced the formation of proliferative tetraploid cells after release from the $\mathrm{G}_{2}$-arrest by this drug ${ }^{5 \text { ) }}$. These observations suggest that trichostatin $A$ will be useful for studying the mechanisms of cell differentiation and the eukaryotic cell cycle.

MORIOKA et al. reported independently that trichostatic acid (Fig. 1) showed a similar effect on Friend leukemia cells, although its effective concentration was about 1,000 -fold higher than that of trichostatin $\mathrm{A}^{6}$. Recently, they have also reported that the racemic form of trichostatic acid had no activity as a differentiation inducer ${ }^{7}$. To verify these observations and the relationship of stereochemistry to biological activity, MORI and KOSEKI synthesized both enantiomers of trichostatin A and trichostatic acid ${ }^{8}$. In this paper, we compared their biological activities, and concluded that $(R)$-trichostatin $\mathrm{A}$, a naturally occurring substance, was the only active agent among these four compounds.

\section{Materials and Methods}

Chemicals and Physico-chemical Measurements

Purified preparations of $(R)$-trichostatin A ( $>$ $93 \%$ enantiomeric excess), $(S)$-trichostatin A ( $>93$ $\%$ enantiomeric excess), $(R)$-trichostatic acid ( $98 \%$

Fig. 1. Structures of trichostatin $\mathbf{A}$ and its related compounds.

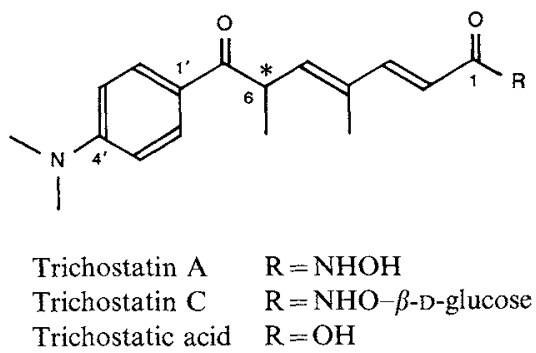


enantiomeric excess), and $(S)$-trichostatic acid (98\% enantiomeric excess) synthesized in the previous work ${ }^{8)}$ were used. Enantiomeric purities of these compounds were determined with HPLC using chiral stationary phase columns (CHIRALCEL-OA and -OB, Daicel Chemical Industries Ltd.). CD spectra were recorded on a Jasco J-20 automatic spectropolarimeter.

\section{Cells and Culture Conditions}

A mouse Friend leukemia cell line, DS19 and a rat embryonic fibroblast cell line, $3 Y 1^{97}$, are cultured in EAGLE's minimal essential medium supplemented with $12 \%$ fetal calf serum (Cell Culture Laboratories) under the same $5 \% \mathrm{CO}_{2}-95 \%$ air atmospheric conditions in a humidified incubator at $37^{\circ} \mathrm{C}$.

\section{Assay of Friend Cell Differentiation}

For detection of the differentiation-inducing activity in Friend leukemia cells, benzidine staining method $^{10)}$ was used after cultivation of Friend cells for 5 days with various concentrations of trichostatinrelated compounds.

\section{Assay of $\mathrm{G}_{2}$-Arrest-inducing Activity in Rat $3 \mathrm{Y} 1$ Fibroblasts}

Rat 3Y1 fibroblasts seeded at $2 \times 10^{5}$ cells/ $60 \mathrm{~mm}$-dish were synchronized in the early $\mathrm{S}$ phase by the method using hydroxyurea as described previously ${ }^{5}$. Cells arrested in the early $\mathbf{S}$ phase were released by washing to remove hydroxyurea and were then exposed to a serum-free medium containing various concentrations of trichostatin-related compounds for 24 hours. In this condition, cells affected by trichostatin activity would be arrested in the $G_{2}$ phase ${ }^{\text {s) }}$ while cells whose growth was not inhibited by drugs would be arrested in the $G_{0} / G_{1}$ phase due to the lack of serum ${ }^{11}$. Therefore, we determined the $G_{2}$-specific inhibitory activity of the drugs by measuring the ratio of the $G_{2}$-arrested cells to the total cells with a flow cytometer. Staining of nuclei and measuring cellular DNA contents by flow cytometry were carried out according to the methods as described previously ${ }^{5}$.

\section{Results and Discussion}

We determined the enantiomeric purities of synthetic $(R)$-trichostatin $\mathrm{A},(S)$-trichostatin $\mathrm{A},(R)$ trichostatic acid, and $(S)$-trichostatic acid before the examination of their biological activities. These compounds were methylated with excess $\mathrm{CH}_{2} \mathrm{~N}_{2}$ and were analyzed by HPLC using chiral stationary phase columns. As shown in Fig. 2(A), peaks of methylated $(R)$ - and $(S)$-trichostatic acid appeared at 33 and 21

Fig. 2. Analysis of enantiomeric purities of synthetic trichostatin-related compounds.

(A) Methylated trichostatic acid (CHIRALCEL-OB, 98\% MeOH, $0.6 \mathrm{ml} /$ minute, detected at $254 \mathrm{~nm}$ ). (B) Dimethylated trichostatin A (CHIRALCEL-OA, $n$-hexane-2-propanol, 9:1, 0.6 ml/minute, detected at $254 \mathrm{~nm}$ ).

(A)

$(R)+(S)$

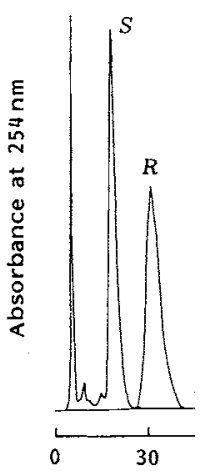

(S)

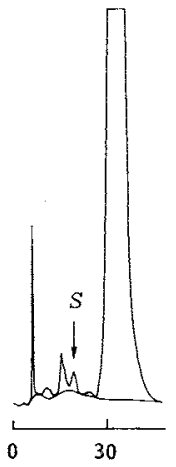

(B)

$(R)+(S)$

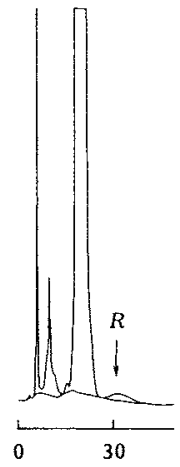

$(R)$

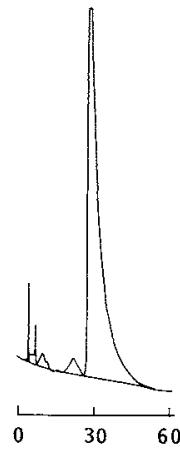

(S)

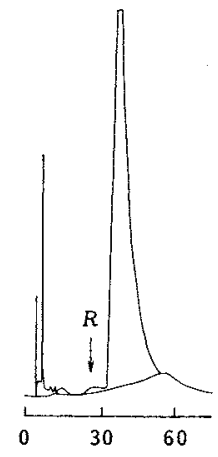


Fig. 3. CD spectra of $(R)$ - and $(S)$-trichostatin A.

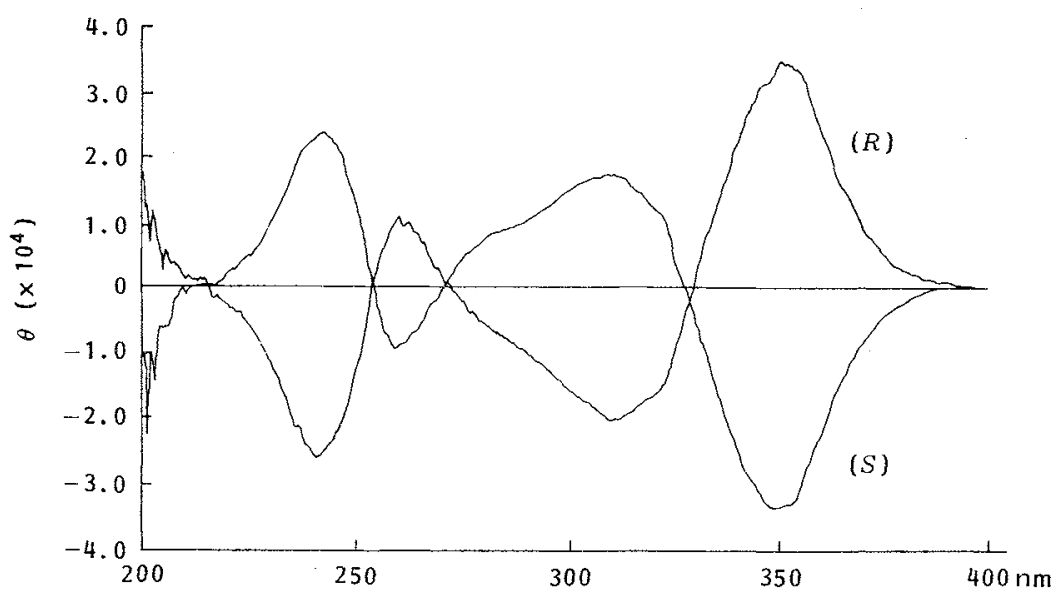

Fig. 4. Effects of trichostatin-related compounds on induction of Friend cell differentiation.

Friend cells were inoculated at an initial density of $10^{5} \mathrm{cells} / \mathrm{ml}$ and cultured in the presence of various concentrations of $(R)$-trichostatin A $(O),(S)$-trichostatin A $(\bullet),(R)$-trichostatic acid $(\square),(S)$-trichostatic acid $(\mathbb{E})$, and natural trichostatin $A(\triangle)$. The percentages of benzidine-positive cells were determined after 5 days of cultivation.

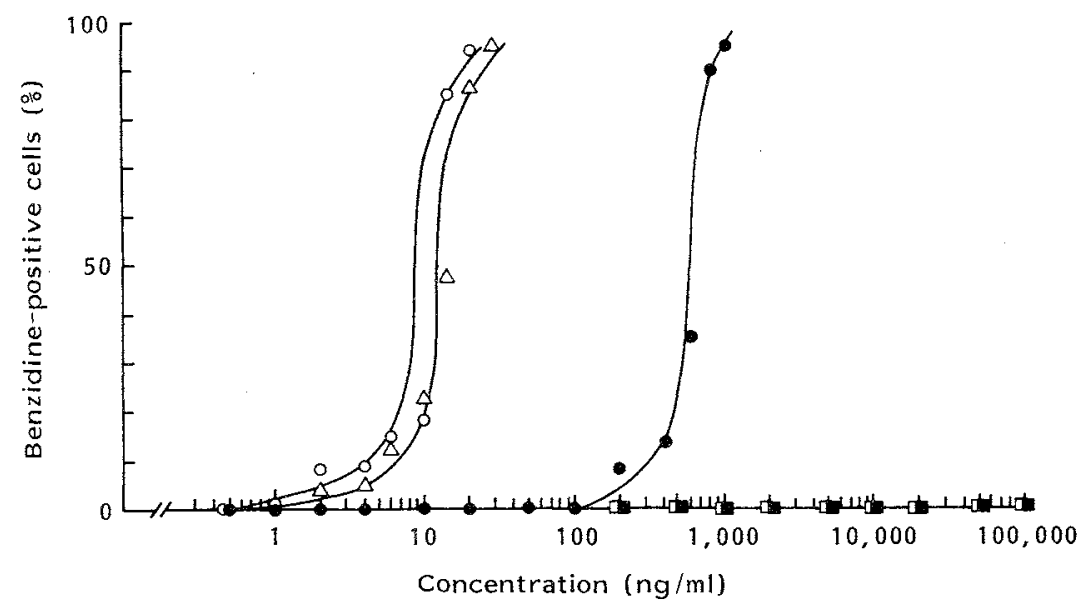

minutes, respectively, and their enantiomeric purities were calculated to be over $98 \%$ from their peak areas. The enantiomeric purities of $(R)$ - and $(S)$-trichostatin A were also analyzed with their methylated derivatives. Reaction with $\mathrm{CH}_{2} \mathrm{~N}_{2}$ gave dimethylated forms as confirmed by ${ }^{1} \mathrm{H} \mathrm{NMR}$, and they were analyzed by HPLC. The Rt's were determined to be 30 minutes for $(R)$-isomer and 37 minutes for $(S)$-isomer (Fig. 2(B)). (R)-Isomer present in the $(S)$-isomer sample was separated and the enantiomeric excess of $(S)$-isomer was estimated as at least $93 \%$, while it was very difficult to determine the purity of $(R)$-isomer by HPLC analysis, since large tailing of the $(R)$-peak interfered with the estimation of the contaminating amount of the $(S)$-isomer. However, the symmetric curves of both isomers of trichostatin $\mathrm{A}$ in CD spectra (Fig. 3) indicated that their enantiomeric purities were almost identical (>93\% enantiomeric excess). These results were consistent with $[\alpha]_{\mathrm{D}}$ values previously described ${ }^{8}$.

We next examined the effects of these trichostatin-related compounds on the differentiation of Friend 
leukemia cells (Fig. 4). (R)-Trichostatin A showed essentially the same activity $\left(\mathrm{ED}_{50}=12 \mathrm{ng} / \mathrm{ml}\right)$ as that of natural trichostatin A isolated from the culture broth of Streptomyces platensis No. 145 ${ }^{4}$. An approximately 50-fold higher concentration $\left(\mathrm{ED}_{50}=640 \mathrm{ng} / \mathrm{ml}\right)$ of $(S)$-trichostatin $\mathrm{A}$ was required for the induction. The weak activity of $(S)$-trichostatin $A$ can be attributed to the contaminating amount of $(R)$-enantiomer, since the $\mathrm{ED}_{50}$ concentration of the $(S)$-trichostatin A preparation (>93\% enantiomeric excess) may contain less than $22 \mathrm{ng} / \mathrm{ml}$ of $(R)$-enantiomer, which is sufficient to express the activity. In the case of trichostatic acid, both of enantiomers showed no inducing effect on Friend cell differentiation at least up to concentrations of $100 \mu \mathrm{g} / \mathrm{ml}$.

Effects of $(S)$-trichostatin A and trichostatic acids on the induction of Friend cell differentiation by $(R)$-trichostatin A were also examined. As shown in Table 1, co-existence of these compounds with $(R)$-trichostatin A caused no inhibitory, additive, or synergistic effects on any concentrations examined.

Effects of both enantiomers of trichostatin A and trichostatic acid on the cell cycle of normal fibroblasts were analyzed with flow cytometry. The proportion of the cells arrested at the $G_{2}$ phase in the synchronous culture starting from the early $S$ phase was monitored as an index of the activity. In the control experiment without the drugs, most of the cells were introduced into the $G_{0} / G_{1}$ phase with $2 C$ DNA content due to serum deprivation, while cultivation with $100 \mathrm{ng} / \mathrm{ml}$ of $(R)$-trichostatin A produced a large number of the $\mathrm{G}_{2}$-arrested cells with $4 \mathrm{C}$ DNA content (Fig. $5(A)$ ). By measuring the ratio of the $\mathrm{G}_{2}$-arrested cells with different concentrations, an $\mathrm{ED}_{50}$ of $(R)$-trichostatin $\mathrm{A}$ for the cell cycle inhibition was estimated to be 35 $\mathrm{ng} / \mathrm{ml}$, while that of $(S)$-trichostatin A was approximately 70 -fold higher $\left(\operatorname{ED}_{50}=2,600 \mathrm{ng} / \mathrm{ml}\right)$, probably due to the contamination by $(R)$-isomer in the preparation. Both enantiomers of trichostatic acid were also found to be inactive in this system (Fig. 5(B)). No competitive effect of $(S)$-trichostatin A, $(R)$-trichostatic acid or $(S)$-trichostatic acid was observed on $\mathrm{G}_{2}$-arrest induced by $(R)$-trichostatin $\mathrm{A}$ (Table 2 ).

These results obtained from the two assay systems clearly indicated that only the $(R)$-trichostatin $A$ corresponding to the natural product is biologically active and $(S)$-trichostatin $\mathrm{A}$ and both enantiomers of trichostatic acid are biologically inactive. These results strongly suggest that both the $R$-configuration at $\mathrm{C}-6$ position and the presence of the hydroxamate group are essential for expression of the biological activity. Results inconsistent with this work upon trichostatic acid reported by MORIOKA et al. ${ }^{6.7)}$ may be due to the contamination of the trichostatic acid preparation by active trichostatin A during the isolation process.

Strict structural specificity of trichostatin A shows a clear contrast to the known inducers of Friend cell differentiation such as DMSO together with butyrate inhibiting the progression of the $G_{1}$ and $G_{2}$ phases in the mammalian cell cycle ${ }^{12 \sim 14)}$. Both of these agents have no chiral center and require very high

Table 1. Effect of trichostatin-related compounds on the induction of erythroid differentiation by $(R)$-trichostatin A.

\begin{tabular}{lrcc}
\hline \multirow{2}{*}{ Compounds } & $\mathrm{ng} / \mathrm{ml}$ & None Benzidine-positive cells \\
\cline { 3 - 3 } & & 0 & $(R)$-Trichostatin A \\
\hline None & 10 & 0 & 87.1 \\
$(S)$-Trichostatin A & 100 & 0 & 88.1 \\
& 1,000 & 0 & 84.3 \\
$(R)$-Trichostatic acid & 10,000 & 0 & 78.3 \\
& 1,000 & 0 & 84.6 \\
$(S)$-Trichostatic acid & 10,000 & 0 & 80.6 \\
\hline
\end{tabular}

a Friend cells were cultured in the presence of $15 \mathrm{ng} / \mathrm{ml}$ of $(R)$-trichostatin A for 5 days with or without the indicated concentrations of other related compounds. The extent of differentiation was determined by benzidine staining. 
Fig. 5. Effects of trichostatin-related compounds on $\mathrm{G}_{2}$ progression in the cell cycle of normal rat $3 Y 1$ fibroblasts.

(A) We showed the flow cytometric patterns of the cells treated with drug-free medium (left) or with $100 \mathrm{ng} / \mathrm{ml}$ of $(R)$-trichostatin A (right) as examples of this assay. (B) Dose response curves of

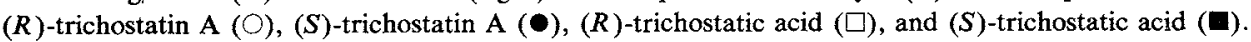

(A)
Control
(R)-Trichostatin A
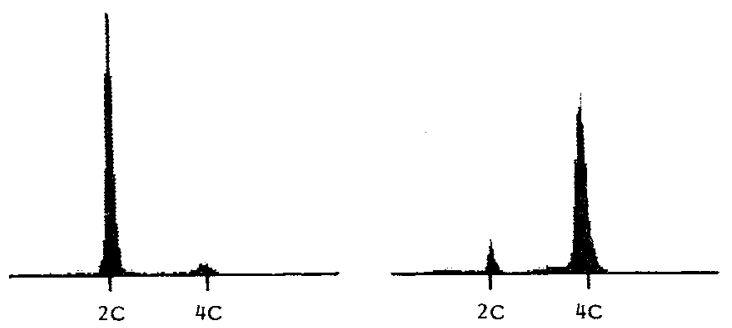

(B)

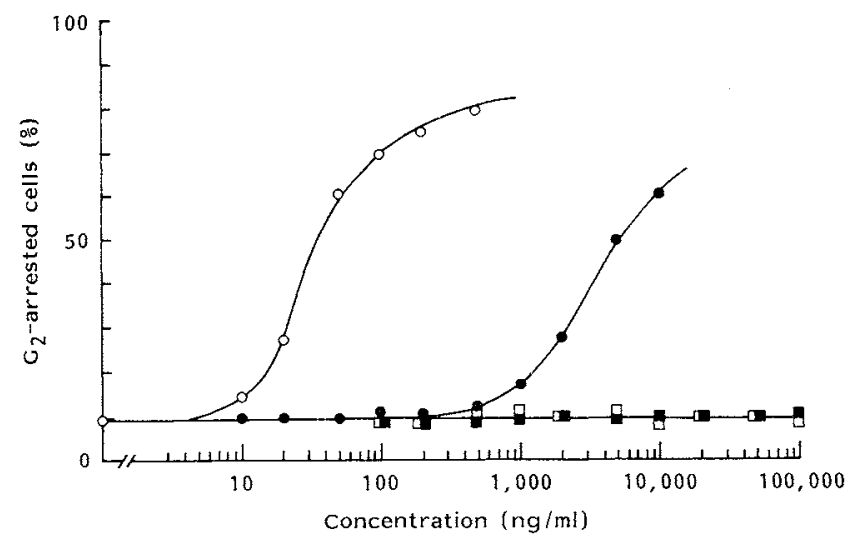

For determining the percentages of $\mathrm{G}_{2}$-arrested cells by trichostatin-related compounds, the early $\mathrm{S}$ starting synchronous culture with serum-free medium as described in Materials and Methods was used.

Table 2. Effect of trichostatin-related compounds on the $G_{2}$-arrest induced by $(R)$-trichostatin $A$.

\begin{tabular}{lrrr}
\hline \multicolumn{1}{c}{ Compounds } & $\mathrm{ng} / \mathrm{ml}$ & None $\mathrm{G}_{2}$-Arrested cells $^{\mathrm{a}}$ & $(R)$-Trichostatin A \\
\cline { 3 - 4 } & & 9.6 & 86.2 \\
None & 10 & 9.8 & 86.9 \\
$(S)$-Trichostatin A & 100 & 10.9 & 85.0 \\
& 1,000 & 17.0 & 83.9 \\
& 10,000 & 58.4 & 84.1 \\
$(R)$-Trichostatic acid & 100 & 9.1 & 85.5 \\
& 1,000 & 10.7 & 85.4 \\
& 10,000 & 9.0 & 82.2 \\
$(S)$-Trichostatic acid & 100,000 & 9.8 & 80.6 \\
& 100 & 9.1 & 84.4 \\
& 1,000 & 10.2 & 84.0 \\
\end{tabular}

a Rat 3Y1 fibroblast cells synchronized in the early $S$ phase were cultured in the presence of $100 \mathrm{ng} / \mathrm{ml} \mathrm{of}$ $(R)$-trichostatin A for 24 hours with or without the indicated concentrations of other related compounds. The extent of the $\mathrm{G}_{2}$-arrest was determined by flow cytometry. 
concentrations ( $280 \mathrm{mM}$ of DMSO and $1 \mathrm{mM}$ of butyrate) for expressing their activities. An extremely low effective concentration and strict structural specificity of trichostatin A suggest specific binding with its molecular target. Identification of the binding protein of trichostatin A will also help our understanding of important mechanisms involved in the regulation of cell proliferation and differentiation.

\section{Acknowledgments}

This work was supported by a Grant-in-Aid for Cancer Research from Ministry of Education, Science, and Culture, Japan.

\section{References}

1) Tsuil, N.; M. Kobayashi, K. Nagashima, Y. Wakisaka \& K. Kolzumi: A new antifungal antibiotic, trichostatin. J. Antibiotics 29: 1 6, 1976

2) Tsuil, N. \& M. Kobayashi: Trichostatin C, a glucopyranosyl hydroxamate. J. Antibiotics 31: 939 944, 1978

3) Yoshida, M.; Y. Iwamoto, T. Uozumi \& T. BEPPU: Trichostatin C, a new inducer of differentiation of Friend leukemic cells. Agric. Biol. Chem. 49: 563 565, 1985

4) YoshidA, M.; S. NomURA \& T. BEPPU: Effects of trichostatins on differentiation of murine erythroleukemia cells. Cancer Res. 47: 3688 3691, 1987

5) YoshidA, M. \& T. BEPPU: Reversible arrest of proliferation of rat $3 Y 1$ fibroblasts in both the G1 and G2 phases by trichostatin A. Exp. Cell Res. 177: 122 131, 1988

6) Morioka, H.; M. Ishihara, M. Takezawa, K. Hirayama, E. Suzuki, Y. Komoda \& H. Shibai: A new differentiation inducer of Friend leukemia cells, trichostatic acid. Agric. Biol. Chem. 49: 1365 1370, 1985

7) MORIOKA, H.; M. IshihaRA, M. TAKEZAWA, H. SHIBAI \& Y. KOMODA: Disappearance of differentiation-induction of Friend leukemia cells upon racemization of trichostatic acid. Agric. Biol. Chem. 52: 583 584, 1988

8) MORI, K. \& K. KOSEKI: Synthesis of trichostatin A, a potent differentiation inducer of Friend leukemic cells, and its antipode. Tetrahedron 44: 6013 6020, 1988

9) KImURA, G.; A. ITAGakI \& J. SUmmers: Rat cell line $3 Y 1$ and its virogenic polyoma- and SV40-transformed derivatives. Int. J. Cancer 15: 694 706, 1975

10) Orkin, S. H.; F. I. HARosi \& P. LEDER: Differentiation in erythroleukemic cells and their somatic hybrids. Proc. Natl. Acad. Sci. U.S.A. 72: $98 \sim 102,1975$

11) OKUDA, A. \& G. KIMURA: Effects of serum deprivation on the initiation of DNA synthesis in the second generation in rat 3Y1 cells. J. Cell. Physiol. 110: 267 270, 1982

12) Fallon, R. J. \& R. P. Cox: Cell cycle analysis of sodium butyrate and hydroxyurea, inducers of ectopic hormone production in HeLa cells. J. Cell. Physiol. 100: 251 262, 1979

13) LARNo, S.; X. RONOT, M. AdolPhE \& P. LECHAT: Effects of sodium butyrate on growth and cell-cycle kinetics of cultured rabbit articular chondrocytes. J. Cell. Physiol. 120: 384 390, 1984

14) Yamada, K. \& G. KIMURA: Formation of proliferative tetraploid cells after treatment of diploid cells with sodium butyrate in rat 3 Y1 fibroblasts. J. Cell. Physiol. 122: 59 63, 1985 